Article

\title{
EU Agencies and the Energy Union: Providing Useful Information to the Commission?
}

\author{
Torbjørg Jevnaker ${ }^{1,2, *}$ and Barbara Saerbeck ${ }^{3,4}$ \\ ${ }^{1}$ Department of Political Science, University of Oslo, 0317 Oslo, Norway; E-Mail: torbjorg.jevnaker@stv.uio.no \\ ${ }^{2}$ Fridtjof Nansen Institute, 1366 Lysaker, Norway \\ ${ }^{3}$ Federation of German Consumer Organizations, 10969 Berlin, Germany; E-Mail: saerbeck@zedat.fu-berlin.de \\ ${ }^{4}$ Environmental Policy Research Centre, Freie Universität Berlin, 14195 Berlin, Germany \\ * Corresponding author
}

Submitted: 15 October 2018 | Accepted: 30 January 2019 | Published: 28 March 2019

\begin{abstract}
The development of the energy policy of the European Union (EU) has been accompanied by organizational reforms of the EU's energy bureaucracy. Much attention has been paid to Commission President Juncker's reorganization of the European Commission, including how this has influenced the Energy Union initiative. The establishment of EU agencies has also expanded the EU administration and the capacity for developing new initiatives and coordinating implementation of EU legislation. However, recent research has not been sufficiently connected to policy studies on energy, climate and environment. This article analyses the extent to which two EU agencies-the Agency for the Cooperation of Energy Regulators, and the European Environmental Agency-augment the policymaking capacity of the Commission by providing information that aids its work. The article ends with a discussion of the potential implications of agencification.
\end{abstract}

\section{Keywords}

Agency for the Cooperation of Energy Regulators; energy policy; Energy Union; EU agencies; European Commission; European Environment Agency; expertise; information

\section{Issue}

This article is part of the issue "EU Energy Policy: Towards a Clean Energy Transition?", edited by Kacper Szulecki and Dag Harald Claes (University of Oslo, Norway).

(C) 2019 by the authors; licensee Cogitatio (Lisbon, Portugal). This article is licensed under a Creative Commons Attribution 4.0 International License (CC BY).

\section{Introduction}

The EU's energy policy has expanded, most recently with broad initiatives like the Energy Union as well as specific policy developments like the Clean Energy Package (European Commission , 2016). The organizational structures in place at the EU level have also evolved. Much attention has been paid to President Juncker's reorganization of the Commission to improve horizontal coordination, including how this has influenced the crosscutting Energy Union initiative (Burgin, 2018). However, other changes have not merely re-structured, but also expanded the EU's administration: agencification refers to the establishment of EU agencies that are executive- administrative entities operating at varying distances from politics. Such agencies provide technical, scientific and managerial expertise, and have mushroomed over the last two decades. A growing literature has examined the emergence and impact of EU agencies in general (see e.g. Blauberger \& Rittberger, 2015; Busuioc, Groenleer, \& Trondal, 2012; Dehousse, 2008; Egeberg \& Trondal, 2011, 2017; Groenleer, 2009; Kelemen \& Tarrant, 2011; Tarrant \& Kelemen, 2017; Wonka \& Rittberger, 2010) and what this development means for the EU (Bickerton, Hodson, \& Puetter, 2015; Genschel \& Jachtenfuchs, 2015). However, this stream of research has not been sufficiently linked to policy studies, including energy, environment and climate policy. 
EU agencies are positioned to make a difference by providing expertise that can underpin new legal initiatives as well as help to implement and monitor existing legislation. By facilitating EU-wide data collection, they provide a better basis for EU policy than aggregating national data-the latter might be coloured by national interests, or be incomparable due to differing sources and methods (Busuioc \& Groenleer, 2014). EU agencies recruit technical experts (Egeberg, Gornitzka, \& Trondal, 2017) who give advice and work together with the Commission in developing regulation (Blom, Suijlekom, Versluis, \& Wirtz, 2014; Jevnaker, 2015; Rimkute, 2015). Although EU agencies have multiple principals (Dehousse, 2008), they have most contact with the Commission (Egeberg, Trondal, \& Vestlund, 2015). The Commission may use the information it receives from EU agencies in several ways-to solve problems instrumentally, or to substantiate or legitimize policy choices (Rimkute \& Haverland, 2015). EU agencies expand the capacities of the Commission by providing it with specialized information, as EU agencies are 'assumed to offer greater transparency, expert authority, flexibility, better informed decisions and better implementation' (Wolff \& Schout, 2013, p. 306). EU agencies may become assets for the Commission, which in turn could gain further leverage vis-à-vis the other EU institutions. As such, agencification in the policy areas of energy and climate policy could strengthen the Commission's capacity for developing policies under the umbrella of the Energy Union.

Scientific, technical and political expertise is not unique: there are academics, consultants and specialist practitioners in abundance across Europe. What enables EU agencies not just to deliver specialized information, but also to provide the Commission with expertise that the latter finds relevant to its work? This article examines the conditions that must be met for the Commission to see information provided by EU agencies as useful. Taking an organizational perspective, we compare the role of organizational characteristics in facilitating the provision of information that the Commission regards as useful. Here we focus on two EU agencies in order to investigate the implications of agencification for the Energy Union: the Agency for the Cooperation of Energy Regulators (ACER) is involved in energy issues, whilst the European Environment Agency (EEA) deals with environment and climate issues. The following section outlines our analytical approach before we delve into our two case studies and compare the contributions of these agencies to the Commission's work. The analysis shows that information provided by these two agencies is found to be useful for the Commission, and we trace this back, among other things, to the similarities in organizational structure of the Commission on the one hand, and our two EU agencies on the other hand. The article ends with a discussion of the potential implications of agencification for EU policymaking.

\section{Examining the Provision of Useful Information}

The Commission today does not lack information: instead, it faces an overload of available information. The challenge is not to provide information as such, but to provide relevant information tailored to meet the needs of policymakers. Identifying the extent to which the Commission regards the input it receives from EU agencies as useful to its work is not a trivial matter. It concerns not only the assigned value of expert knowledge, but also the degree to which such information can be utilized by the Commission in its policymaking processes. As the Commission has experienced staff with extensive substantial and procedural knowledge, it presumably has less need for information that can be obtained in-house. However, the Commission is more likely to find additional information provided by EU agencies relevant or helpful if this complements the Commission's own expertise. An EU agency must take into account the needs of the Commission and supply relevant information that aids or complements the Commission's expertise. We measure such 'usefulness' by assessing the extent to which members of the Commission describe agency inputs as useful. Here we include statements on relevance, usefulness and interest, as well as descriptions of what is seen as the Commission's lack of in-house expertise, and mentions of the need for complementary expertise.

Here we consider factors that facilitate interaction between EU agencies and the Commission so that the latter recognizes the benefits of information provided by the former. Rather than considering factors that enable information provision by agencies per se, we seek to explain how agencies provide information that is deemed useful by the Commission itself. Drawing on organizational theory-which holds that organizational structure and demography affect organizational behaviour (Egeberg, 2012)-we argue that the ability of EU agencies to deliver information useful to the Commission depends on the organizational characteristics of these agencies as well as those of the Commission.

Firstly, the organizational structure of an EU agency may shape its ability to deliver relevant information. As we are interested not in organizational behaviour as such, but in organizational behaviour towards an environment, we draw on the concept of 'organizational congruence' (Kieser \& Kubicek, 1992; Saerbeck, 2014): an organization is expected to be more successful if its organizational structure fits with its environment. For example, Klüver (2012) found that staff in EU interest groups with an organizational structure similar to that of the Commission were able to specialize and become experts in their field. In turn, this specialization enabled them to become part of a policy community that also included Commission officials. As networked specialists, they were adept at monitoring developments within the Commission, and could prepare for the provision of relevant information needed by the Commission (Klüver, 2012). Thus, organizational congruence facilitated net- 
work building and monitoring, helping these experts to provide information that the Commission found useful and-perhaps as importantly-timely. Following Klüver, we argue that organizational congruence strengthens inter-organizational information exchange because of shared tasks and topics. The more similarity in organizational structure of an EU agency to that of the Commission, the more likely is information exchange to occur. We expect an EU agency whose internal organization resembles or even 'overlaps' that of the Commission to be more adept at delivering relevant information to the Commission. Here, we compare the horizontal and vertical specialization of the EU agency with that of the 'lead' Directorates-General (DGs) in a policy-area (i.e., the DG responsible for a given policy-area). This shared specialization enables an EU agency to work on similar tasks as the Commission, which is conducive to network building. In turn, this enables the agency to monitor developments in the Commission. The ability to pick up signals is vital for the agency to be able to deliver relevant information in a timely manner.

A second major organizational variable is demography. Personal networks enable EU agency staff to tune into not just the working mentality of their counterparts, but the political signals as well. Thereby, the EU agency can adjust its behaviour accordingly-in order to provide relevant and targeted information to the Commission. We expect the terms of recruitment and employment to shape the ability of an agency to deliver information that the Commission regards as relevant. The agency's demography is also related to the importance of networks. Previous research has found length of service of staff to be an important organizational characteristic for staff behaviour (Egeberg, 2012). We argue that the terms of employment in an agency define its ability to interact with the Commission DGs: Temporary employment weakens agency personnel's 'technical and scientific knowledge on the policy problem, administrative and procedural knowledge...as well normative and diplomatic knowledge' (Bauer, 2006, p. 30). Moreover, it hinders the establishment of personal networks with contact persons in the targeted division. Thus, contract length will be an important determinant for an EU agency's ability to deliver relevant and timely information to the Commission. Low staff rotation minimizes the risk for loss of institutional memory and helps to facilitate and strengthen personal ties, build trust and hence, a professional network with relevant persons within the DGs. Overall, the demography of the agency in question will facilitate the provision of information that the Commission regards as relevant.

We conducted 22 semi-structured interviews with individuals well positioned to participate in or closely observe the agencies, and particularly their contact and interaction with the Commission. Informants came from various levels within the two EU agencies as well as from the Commission, with interviews with high-level representatives and policy officers. We also interviewed close observers such as national agencies and interest groups ${ }^{1}$. Informants were queried about the nature of the relationship in general and the extent of interaction and cooperation between staff in the EU agency and the Commission, as well as about informal contacts. Moreover, we asked informants about the role of the organizational setup and demography of EU agencies for coordinating with the Commission. To measure complementary information, we asked informants to compare the in-house expertise of the EU agency with that of the relevant division in of the Commission. In addition, we asked Commission representatives whether, when and how they made use of information provided by ACER or EEA. Finally, we asked the interviewees whether other factors might affect the relationship between the Commission and EU agencies, in order to get better insights into this hitherto unexplored area. Documentary data were collected from official documents published by the selected EU agencies as well as from the Commission. We studied the organigrams of the selected agencies and the Commission in order to study the level of organizational congruence and to identify structural similarities between sender and recipient. Here, we compared the relevant Commission Directorate-General (DG) with the respective agency (e.g. ACER-DG Energy). We checked whether the same specialization principle had been applied for the division of labour. For the role of demography, we examined the length of postings within each agency.

\section{ACER and EEA: How to Provide Information Actually Used by the Commission?}

In this section, we consider the organization and demography of ACER and EEA, before assessing the extent to which they provide information that the Commission finds useful. This is followed by a comparative discussion.

\subsection{The Agency for the Cooperation of Energy Regulators}

ACER works together with the Commission in developing harmonized rules for cross-border electricity and gas networks ('network codes'), and in allocating EU funding to help build prioritized cross-border networks ('projects of common interest') (EU, 2009b, 2009c, 2013). ACER also collects data on wholesale energy markets across Europe in order to monitor for market abuse (EU, 2011).

\subsubsection{Organizational Congruence}

ACER has four operational departments: electricity, gas, market surveillance and conduct, and market in-

\footnotetext{
${ }^{1}$ Interviews were conducted between 2013 and 2015, each lasting 30-90 minutes. Interviews 1-10 concerned the EEA: number 1-3 and 10 were with Commission staff and number 4-9 with members of the EEA. Interviews 11-22 concerned ACER: number 14-17 and 22 were with agency staff; 11 , 12 and 18-20 with Commission staff; number 13 was with an interest group representative, and number 21 with a national agency.
} 
tegrity and transparency. The electricity and gas departments concentrate on network codes, retail markets and projects of common interest within their respective sectors, while the market monitoring departments keep a keen eye on financial transactions in wholesale electricity and gas markets. ACER activities are related to Directorate B (internal energy market) within the Commission's DG Energy, which is specialized by function: unit B1 'Networks \& Regional Initiatives' deals with network construction, including projects of common interest; and unit B2 'Wholesale markets; electricity \& gas' is involved in harmonizing network management (network codes). ACER and the Commission do not seem very congruent in terms of their internal organization. In ACER, the internal division of labour is partly by sector, partly by function, whereas the Commission has a 'purer' functional specialization. However, we noted an informal use of the sector principle for the Commission: Despite the absence of separate units for electricity and gas, there is an informal distribution of labour along sector lines within the Directorate B units. For electricity, for instance, it was in practice 'quite clear who was supposed to talk to whom' (Interview 11).

A high degree of specialization facilitated contact and network building between staff members in ACER and the Commission. Informants from both sides noted the low number of people that they needed to coordinate with within the other organization (Interviews 11, 12, 14, 16). This means that Commission staff can get well acquainted with the people working in ACER (Interviews 11, $12,14,16)$. Moreover, both the Commission and ACER were involved in tasks related to network-code development and projects of common interest. Joint involvement in processes fostered regular exchange at all levels. There were multiple contact points between ACER and the Commission regarding implementation of existing legislation or the preparation of new legislation, including on market design (Interviews 11, 12, 14, 16). Regarding market monitoring, staff in both organizations were involved in the process of preparing the implementation of legislation, and had extensive contact since they were working on similar issues. Following the completion of this process in December 2014, however, ACER was to continue to focus on the monitoring of financial energy markets, whereas the Commission would be less involved in this area (Interview 16). Overall, our interviewees indicated that involvement in the same processes was more important for inter-organizational contact than the formal specialization principle. In sum, then, the combination of high specialization of staff in both organizations and participation in the same processes facilitated networking, contact and exchange of information between the Commission and ACER.

\subsubsection{Demography}

ACER employs temporary agents (5-year contracts), contract agents (max. 3 years), and seconded national ex- perts ( 2 years). There were routines for maintaining institutional memory despite staff turnover, with emphasis on documentation (e.g. writing manuals) (Interview 22). ACER consciously recruited personnel with substantial experience within the field (Interview 22). Most employees were already familiar with the issues at hand. Several informants in ACER noted that they had been in contact with the Commission prior to working for ACER. Thus, as regards networking, recruiting personnel already engaged within the field seems more important than length of employment. Hiring networked staff facilitated overall interaction between ACER and the Commission. Further contact was also facilitated by the low number of Commission staff involved in each specialized field, along with the joint involvement of the Commission and ACER in formal processes. Staff from the two organizations either already knew each other, or found it easy to become acquainted. Such personal networks aided the informal exchange of information between ACER and the Commission. While demographic changes (turnover) could pose a challenge, this was ameliorated by the extensive contact between ACER and the Commission due to their joint involvement in regulatory processes. However, we should mention that, as of our interview period, significant turnover had not yet really had the time to occur.

\subsubsection{Discussion: ACER-Information Useful to the Commission?}

As noted, organizational structure and demography facilitated contact and networking between ACER and the Commission. To what extent did this lead the Commission to see input from ACER as useful? Informants from the Commission explained that they had in-house expertise on 'internal market issues' themselves, mentioning network codes and projects of common interest. As regards market monitoring, however, they noted ACER's expertise and their own lack of such expertise-a point even highlighted in the preamble of the relevant EU legislation (EU, 2011). It was emphasized that market monitoring and oversight over individual transactions was not the type of activity that the Commission should conduct (Interview 12). The Commission relied more on information from ACER on market monitoring, and less so on network management and construction. Although acknowledging the Commission's own expertise, informants acknowledged the greater expertise within ACER at the level of detail (Interviews 11, 12, 13). ACER staff generally had more expertise than the Commission on the technically detailed content of the electricity network codes, for example (Interview 13). Commission staff confirmed this, adding that it would have been more difficult for them to work on the details (like network codes) for the internal energy market without the deeper technical insights provided by ACER (Interview 11). Given the technicalities in question, discussing these issues would have been more difficult for the Commission (Interview 11). When going through member-state comments in comi- 
tology on network codes, the Commission would consult with ACER (Interview 11). Not only did this lessen the Commission's workload, the Commission also made strategic use of ACER's expertise to garner support for its own comitology proposals. The Commission invited ACER to comitology meetings as an expert to explain sections in a given network code to (sceptical) member-state representatives (Interview 19).

The Commission viewed ACER as a 'service provider' that supplied the Commission with information on market developments within the electricity and gas sectors. ACER outputs, like the annual market monitoring report, were highlighted as useful, although the Commission also thought that these could have been more closely targeted. A Commission informant noted that this information was very detailed and needed a clearer narrative in order for the overall picture to emerge from all the details (Interview 12). ACER was referred to as a 'daughter company' that served as a major tool for implementation (Interview 11). The high specialization of ACER's work, which complemented that of the Commission, contributed to making input from ACER very useful to the Commission.

While ACER's in-depth expertise was in demand, some informants pointed out that its internal decisionmaking process reduced the extent to which the Commission could rely on ACER. Representatives of all $28 \mathrm{EU}$ national energy regulators sit on the board of ACER, and hold a prominent position within the agency. As a result, content was watered out to make it politically acceptable to all. As ACER output could be heavily coloured by national interests, the Commission saw the need to take a more active role in re-writing draft network codes, for better harmonization (Interview 13). ACER's internal decision-making processes were seen as spurring greater involvement of the Commission in developing legislation (e.g. network codes), where the Commission made changes to what had been received from ACER. A stronger role for the ACER director vis-à-vis the board might have fostered stronger input from ACER that could be included in final comitology drafts.

In general, however, ACER was praised for its indepth information, and the Commission relied on ACER for the provision of technical expertise. The organizational structure, which was more congruent in practice than on paper, ensured relevance and the creation of networks. The role of demography-recruitment and tenure-was less important to the creation of networks. All in all, the Commission saw ACER as a provider of useful information.

\subsection{The European Environment Agency}

The EEA is urged to 'provide sound, independent information on the environment...for those involved in developing, adopting, implementing and evaluating environmental policy' (EEA, 2018a) so that it may formulate and implement environmentally sustainable policies (EU 2009a, Art. 1, para. 2a).

\subsubsection{Organizational Congruence}

EEA is organized along functional lines, similar to the Commission's DG Environment and DG Climate Action, with which the EEA collaborates. Closer examination of the tasks of the EEA as compared with to the topics discussed within DG Environment and DG Climate reveals considerable overlapping. While, for example, the EEA unit 'climate change, energy and transport' studies climate-change impacts and mitigation processes (EEA, 2018b), DG Climate Action evaluates the effectiveness of European and international climate policies, develops an international carbon market and is responsible for the European Emission Trading System (European Commission, 2018a). Directorate ' $C$ ' of DG Environment is chiefly responsible for matters concerning the marine environment and the quality of water and air (European Commission, 2018b); this is paralleled by the EEA unit 'natural capital and ecosystems' that focuses on, inter alia, biodiversity, water and marine environment (EEA, 2018b). That said, the EEA was heavily involved in assisting the organizational setup of DG Climate Action (Interview 2), which might have led to the similar setup of the latter.

Although the EEA complements the organizational structure of its parent DGs (DG Environment and DG Climate), interviews revealed that exchange between this EU agency and the Commission has been stimulated mainly by the actions of top-management officials. Recognizing the advantages of cooperation, they took action to ensure that EEA staff-members were invited to inter-service consultations of the Commission and to ensure synchronization of work programmes (Interviews 1, 4, 5, 6; see also Groenleer, 2009; Martens, 2010). Moreover, cooperation between the Commission and EEA emanated from evolving practice and not from organizational congruence. In the first years of its existence, the EEA operated from within DG Environment. Moreover, most of its staff were former Commission employees (Interview 2). Although Commission staff would sporadically consult the organigram of the EEA to identify relevant counterparts (Interview 1), they tended to build on existing relationships. These relationships had been established at previous events, via colleagues, or facilitated by the EEA liaison office in Brussels (Interviews 3, $4,5,6,8)$. In sum, already-established personal relationships fostered the exchange of information rather than organizational congruence.

\subsubsection{Demography}

Although the overall number of permanent EEA staff has increased over the years, roughly $40 \%$ of EEA staff in 2011 consisted of contract agents and seconded national experts (Interview 6; COWI, 2013). Many professional staff leave after one to eight years. In practice, the EEA found informal ways to extend contracts (Interview 7), but informal channels of communication to the EU institutions might be lost due to staff rotation. Rebuilding such chan- 
nels for intra- and inter-organizational relationships takes time and resources (Interview 7). Studies also reveal a 'certain delay in filling the established posts' of the EEA (COWI, 2013). Thus, the EEA risked losing valuable expertise, because of employees leaving before they had a chance to train their replacements properly-and that involves expertise vital to the EEA, to ensure the quality of their products and their ability to act, as our respondents pointed out (Interview 1, 4, 7, 9). To avoid loss of expertise and networks, the EEA focused on continuously expanding its data-storage systems and developing smart recruitment strategies. Thus, many EEA staff members had previously worked on environmental issues in other institutions on various levels (Interview 6). They were more likely to be already acquainted with members of the Commission, which has further facilitated initial contact and mutual trust. In sum, although the EEA found ways to circumvent the challenges of temporary staff employment, it still struggled not only with loss of institutional memory and expertise, but also with the loss of personal networks.

\subsubsection{Discussion: EEA-Information Useful to the Commission?}

The founding regulation urges the EEA to avoid activities 'duplicating the existing activities of other institutions and bodies' (EU 2009a, art. 3). This recommendation was followed up through an agreement between the DirectorGeneral of DG Environment and the Executive Secretary of the EEA, stating that both organizations should complement rather than duplicate each other's work (Interview 1). Organizational congruence might have had positive effects on the frequency of information exchange between the EEA and the Commission's DGs. As we have seen, however, this cannot in itself have been sufficient to foster information exchange, as the top management in these organizations saw the need for routines that could ensure that this would happen. That goes contrary to our initial assumption. By contrast, demography seems to have facilitated contact and networking between EEA and the Commission, thereby confirming our assumption on that point.

To what extent did the Commission define EEA inputs as useful? Interviewees mentioned regular exchanges on technical as well as policy-related contents and issueframing, between members of the EEA and members of the Commission operating on all levels (Interview 1, 3, 4; Saerbeck, 2014). Moreover, members of the Commission considered information provided by the EEA as helpful (Interview 1, 3, 4, 8):'[i]n many respects, the agency may be regarded as an advisory body to the Commission' (Khuchua, 2009, p. 91). The Commission itself also referred to the EEA as one of its most important partners (Interview 3; Egeberg \& Trondal, 2011). Approximately $70 \%$ of Commission staff at the administrative level working on issues related to the environment and climate reporting using information provided by the EEA when for- mulating policies (COWI, 2013; Saerbeck, 2014). As one informant from the Commission put it, 'we do not rely on the EEA entirely, of course, for information...but the information from the agency is hugely valuable' (Interview 1 ). These findings relate to the limited capacities of the Commission: as one Commission informant pointed out concerning cooperation with the EEA: 'the actual development stage of the policy...normally only one or less than one person is working for one policy area. Those individuals will cultivate relationships with EEA counterparts' (Interview 10). The same informant added that it was 'necessary to have scientific information that is provable and scientifically...and legally sound, and the EEA with its vast range of information...is very useful indeed'; further, that the 'credibility of the agency's reporting is generally higher' (Interview 10). Commission members regarded EEA information as not only useful, but even essential to their work.

\subsection{Comparing Agencies: Aiding the Commission}

What factors made it possible for the two EU agencies to provide information that the Commission considered useful? First, we found that organizational congruence strengthened the usefulness of information provided by the agencies. Specifically, highly specialized work on similar topics fostered contact with the Commission, because this meant that rather small groups of people were working on the same issues across the agency and the Commission (as with DG Energy and ACER). However, agency-Commission contact was also facilitated by formal arrangements like management-planned dialogue (EEA) and joint involvement in the same regulatory procedures (ACER). The organizational similarities between agency and Commission were not complete, but the organization of work triggered contact and facilitated networking between the agencies and the Commission. However, in the absence of joint involvement in formal processes, additional steps might be required to ensure contact. Second, that agency staff had pre-existing networks with the Commission was important for the latter in terms of judging whether the information provided by the agencies was useful. Demography was important for the EEA, but not for ACER, where recruitment and tenure played less of a role for contact and networking with the Commission, due to the highly specialized nature of the tasks involved. There was a small number of people in ACER and DG Energy working on the same issues, and, due to joint involvement, they would meet regularly anyway. In contrast, demography was important for the Commission's perception of information from the EEA as useful: some EEA staff members had previously worked for the Commission, and this positioned them with strategic networks to the Commission that they could use to highlight the usefulness of their agency's information to Commission members. Nevertheless, for the EEA, rapid turnover remained a challenge, so the agency sometimes sought to bend the rules in order to extend contracts. 
We found that the Commission was more likely to consider and act on information provided by EU agencies if they considered it to be useful. For example, the EEA was actively involved in the preparation and drafting of a Commission proposal because the agency provided expertise that complemented the needs of the Commission DGs and because the proposal was written 'in a way policymakers can understand and are able to draw their own conclusions' (Interview 5, see also Interview 18). ACER was also credited by the Commission with providing additional expertise, especially at the level of technical detail. ACER's ability to expand on and discuss the details of energy-sector practices was seen by the Commission as crucial to its work on rule harmonization (network codes), and to the development of an internal energy market in Europe. Both ACER and the EEA were characterized as supporting the Commission's work by providing relevant information that the Commission found useful. This is also indicated by the terminology that the Commission used to describe EEA ('advisory body') and ACER ('service-provider') in relation to the Commission.

In general, it cannot be assumed that the Commission will automatically consider information provided by EU agencies as useful, even though agency expertise is a key rationale behind agencification. The mere presence of expert information from EU agencies is not always sufficient. To some extent, the differences in the type of expertise held by the agencies as compared to that of the Commission could even be a challenge. Differing perspectives did not always result in a well-targeted input from ACER to the Commission. It was also noted that the input format-formal, relatively technical reports-was not always tailored to the Commission as an 'audience', which would have preferred a more political narrative in ACER's technical reports (Interview 12). On the other hand, the EEA ensured not only that additional expertise would be supplied, but also that it would be delivered in a format appropriate to the Commission's needs. The EEA has learned to provide targeted information-even developing formal routines for this. Summing up, we find that both the EEA and ACER have gradually accumulated experience in how to deliver their inputs to the Commission.

\section{Conclusions: EU Agencies as Assets, but not without Pitfalls}

What does agencification entail for EU energy and climate policy-and more broadly, for the development of an Energy Union? EU agencies are positioned to offer technical information with a European perspective, and as such represent a valuable source of relevant information that the Commission can apply in developing new policies or preparing legislation for implementation. Being required to work with various actors operating at different levels, EU agencies are often better informed about, for instance, European energy and environmental issues than other actors. For example, we found that the EEA was seen as a highly legitimate entity that pro- vided impartial expertise in a way that helped policymakers to grasp the deep complexity and uncertainty of the issues at hand. As one member of the EEA stated: 'our strength comes from the fact that we as EEA are seen as independent actors who do not pursue their own interests or lobbying in the broadest sense, and who cooperate very closely with their network' (Interview 8).

Being able to draw on expert knowledge has become central to policymakers in legitimizing their decisions because it lends authority to policy positions, helping to substantiate specific preferences in case of political contestation (Boswell, 2008). According to Riley and BrophyBaermann, 'it isn't so much the possession of expert knowledge but the reaction to-respect for-that knowledge that gives an agency power' (2006, p. 99). Generally, agencification signals independent expertise. In deliberative settings, access to agency expertise should give the Commission added leverage. The Commission may strategically exploit information provided by EU agencies to strengthen its position in the policy-making process (e.g., Groenleer, 2009). Put differently, 'the more technical and complicated the matter becomes, the less politicians and lawyers will dare contest the Agency's opinion' (van Ooik, 2005, p. 141)-and thus, that of the Commission.

Our findings do not necessarily mean Commission dominance, however. Scholars have argued that the rise of EU agencies has come at the expense of the Commission. Bickerton et al. (2015) see EU agencies as a compromise whereby EU integration is not accompanied with new competences to the Commission, and that EU agencies become empowered instead of there being further expansion of the Commission. Even if EU agencies were to become the 'extended arm' of the Commission, member states have their own public administrations. Rather than giving the Commission an information advantage, EU agencies might reduce the Commission's information disadvantage vis-à-vis member states.

We found that both ACER and EEA offered in-depth expertise that aided the Commission, enabling it to develop detailed, specific energy, climate and environmental policies. By being able to draw on expert information organized at the EU level, which entails more consistent data collection and analysis, the Commission is better positioned not only to make policy changes at the level of goals and instruments, but also to go into greater detail by developing changes at the level of instrument settings (Hall, 1993). This is a major advantage to the Commission, enabling it to bring EU agencies as technical experts to its negotiations with the member states.

However, agency expertise may be strategically presented as more independent than it actually is. The autonomy of agencies is often seen as important for their provision of independent expertise. However, the level of formal autonomy varies across EU agencies (Wonka \& Rittberger, 2010). Low agency autonomy is often seen as being in conflict with independent expertise, because it allows agencies less leeway to adjust how they conduct 
their work (Wonka \& Rittberger, 2010). ACER and EEA have low levels of formal autonomy (see Wonka \& Rittberger, 2010; own calculations) ${ }^{2}$. With low autonomy (formally or in practice), commitment is likely to be less credible, and the agency more likely to be responsive to the interests of one or more of its principals. Indeed, both EEA and ACER have sought to improve targeting of the information that they provided to the Commission. Although this could facilitate the delivery of information considered useful by the Commission, an agency's distance from politics might be less than officially recognized and its expertise less independent.

Commission reliance on EU agencies is not without pitfalls. As the relations between a Commission DG and an EU agency mimic domestic ministry-agency relations, challenges familiar from the study of principal-agent relations arise. A major risk is shirking by the agent-in this case a EU agency-also known as 'agency drift': EU agencies may develop an institutional self-interest and exploit the information asymmetry vis-à-vis the principal to pursue other goals than those it was established by the same principal to achieve (Elgie, 2002). In recent years, EU agencies have successively expanded their competencies and reinterpreted their role (Egeberg, Martens, \& Trondal, 2012; Maggetti, 2009). There are indications that EU agencies sometimes follow their own agenda even as they aid the Commission. We found that ACER and the EEA held their own views on several topics. ACER both anticipated what might interest the Commission (e.g., as regards market monitoring reports), but also held its own views (according to Interview 11). Moreover, ACER was beginning to draw out the more political messages from their technical analyses, as could be observed in the subsequent launch of a forward-looking strategy paper on the internal energy market (ACER, 2014). This development occurred even though ACER was heavily regulated and faced resource constraints, which should have limited its capacity to launch political initiatives. Our interviewees made similar statements on a more active role concerning the EEA. Our findings indicate that agencies have become more than mere generators of information: they play roles of tremendous significance, perhaps beyond what policymakers originally foresaw.

Thus, information from EU agencies may help the Commission to build an Energy Union, but EU agencies might seek to pull it in another direction than that envisaged by the Commission. Over time, EU agencies taking action could shape the kinds of issues that are debated, how issues are framed, and the attention paid to various issues. Future research should examine whether EU agencies with higher autonomy contribute in ways similar to the two agencies studied here, or are more prone to drift. The study of the political role of EU agencies is an emerging field for research, where EU agencies could be re-conceptualized as strategic actors, as attentionseeking policy advocates who actively participate in (in- direct) policymaking while employing their own agendas. Concerning the Commission side, scholars should explore to what extent it relies on agency input relative to other sources of information such as expert groups, consultants and public consultations. In sum, more research is needed on how EU agencies operate in practice, as well as on the development of the relationship between EU agencies and the Commission, which, as noted by Trondal and Peters (2013) together comprise an important part of the EU administrative space.

\section{Acknowledgments}

E.on Stipendienfonds provided a mobility grant in spring 2015 that facilitated the research process. Support was also provided from the Centre for International Climate and Energy Policy (CICEP). We would like to thank Åse Gornitzka, Morten Egeberg, Helge Jörgens, Tor Håkon Jackson Inderberg, Inga Ydersbond, Karl H. Bjurstrøm, Stine Hesstvedt and Ida Dokk Smith for very valuable comments. We are also grateful to the four anonymous reviewers that provided useful and constructive comments, and last but not least to Susan Høivik for language editing.

\section{Conflict of Interests}

The authors declare no conflict of interests.

\section{References}

Agency for the Cooperation of Energy Regulators. (2014). Energy regulation: A bridge to 2025 conclusions paper. Recommendation of the Agency on the regulatory response to the future challenges emerging from developments in the internal energy market. Ljubljana: Agency for the Cooperation of Energy Regulators.

Bauer, S. (2006). Does bureaucracy really matter? The authority of intergovernmental treaty secretariats in global environmental politics. Global Environmental Politics, 6(1), 23-49.

Bickerton, C. J., Hodson, D., \& Puetter, U. (2015). The new intergovernmentalism: European integration in the post-Maastricht era. Journal of Common Market Studies, 53(4), 703-722.

Blauberger, M., \& Rittberger, B. (2015). Conceptualizing and theorizing EU regulatory networks. Regulation and Governance, 9(4), 367-376.

Blom, T., Van Suijlekom, L., Versluis, E., \& Wirtz, M. (2014). The politics of information in the EU: The case of European agencies. In T. Blom \& S. Vanhoonacker (Eds.), The politics of information: The case of the European Union (pp. 93-108). Basingstoke: Palgrave Macmillan.

Boswell, C. (2008). The political functions of expert

\footnotetext{
${ }^{2}$ Ranging between 0 and 1 ( 0 indicates low independence), EEA's independence score is 0.21 (Wonka \& Rittberger, 2010). Using the same method, we calculated the score for ACER (0.16).
} 
knowledge: Knowledge and legitimation in European Union immigration policy. Journal of European Public Policy, 15(4), 471-488.

Burgin, A. (2018). The impact of the reorganised Juncker Commission on the internal policy-making process: Evidence from the Energy Union project. Public Administration. https://doi.org/10.1111/padm.12388

Busuioc, M., \& Groenleer, M. (2014). The theory and practice of EU agency autonomy and accountability: Early day expectations, today's realities and future perspectives. In M. Everson, C. Monda, \& E. Vos (Eds.), European agencies in between institutions and member states (vol. 34, pp. 1-30). Alphen aan den Rijn: Kluwer Law International.

Busuioc, M., Groenleer, M., \& Trondal, J. (2012). The agency phenomenon in the European Union: Emergence, institutionalisation and everyday decisionmaking. Manchester: Manchester University Press.

COWI. (2013). Evaluation of the European Environment Agency (Final Report). Kongens Lyngby: COWI.

Dehousse, R. (2008). Delegation of powers in the European Union: The need for a multi-principals model. West European Politics, 31(4), 789-805.

Egeberg, M. (2012). How bureaucratic structure matters: An organizational perspective. In B. G. Peters \& J. Pierre (Eds.), The SAGE handbook of public administration (pp. 157-168). London: SAGE.

Egeberg, M., Gornitzka, Å., \& Trondal, J. (2017). Meritbased recruitment boosts good governance: How do European Union agencies recruit their personnel? International Review of Administrative Sciences. https://doi.org/10.1177/0020852317691342

Egeberg, M., Martens, M., \& Trondal, J. (2012). Building executive power at the European level: On the role of EU-level agencies. In M. Busuioc, M. Groenleer, \& J. Trondal (Eds.), The agency phenomenon in the European Union (pp. 157-179). Manchester: Manchester University Press.

Egeberg, M., \& Trondal, J. (2011). EU-level agencies: New executive centre formation or vehicles for national control? Journal of European Public Policy, 18(6), 868-887.

Egeberg, M., \& Trondal, J. (2017). Researching European Union agencies: What have we learnt (and where do we go from here)? Journal of Common Market Studies, 55(4), 675-690.

Egeberg, M., Trondal, J., \& Vestlund, N. M. (2015). The quest for order: Unravelling the relationship between the European Commission and European Union agencies. Journal of European Public Policy, 22(5), 609-629.

Elgie, R. (2002). The politics of the European Central Bank: Principal-Agent theory and the democratic deficit. Journal of European Public Policy, 9(2), 186-200.

European Union. (2009a). Regulation (EC) no 401/2009 of the European Parliament and of the Council of 23 April 2009 on the European Environment Agency and the European Environment Information and Observation Network. Brussels: European Union.

European Union. (2009b). Regulation (EC) no 713/2009 establishing an agency for the cooperation of energy regulators. Brussels: Official Journal.

European Union. (2009c). Regulation (EC) no 714/2009. Regulation on conditions for access to the network for cross-border exchanges in electricity. Brussels: Official Journal.

European Union. (2011). Regulation (EU) no 1227/2011 on wholesale energy market integrity and transparency. Brussels: Official Journal.

European Union. (2013). Regulation (EU) no 347/2013 on guidelines for trans-European energy infrastructure. Brussels: Official Journal.

European Commission. (2016). Communication form the Commission to the European Parliament, the Council, the European Economic and Social Committee, the Committee of the Regions and the European Investment Bank: Clean Energy for All Europeans. COM(2016) 860 final, 30 November. Brussels: European Commission.

European Commission. (2018a). Who we are. European Commission. Retrieved from https://ec.europa.eu/ clima/about-us/chart_en

European Commission. (2018b). DG Environment. Organisational chart. European Commission. Retrieved from http://ec.europa.eu/dgs/environment/ pdf/org_en.pdf

European Environmental Agency. (2018a). Who we are. European Environmental Agency. Retrieved from https://www.eea.europa.eu/about-us/who

European Environmental Agency. (2018b). Organisational chart. European Environmental Agency. Retrieved from https://www.eea.europa.eu/de/aboutus/who/organisational-chart

Genschel, P., \& Jachtenfuchs, M. (2015). More integration, less federation: The European integration of core state powers. Journal of European Public Policy, 23(1), 42-59.

Groenleer, M. (2009). The autonomy of European Union agencies (Unpublished Doctoral dissertation). Universiteit Leiden, The Netherlands.

Hall, P. A. (1993). Policy paradigms, social learning, and the state: The case of economic policymaking in Britain. Comparative Politics, 25(3), 275-296.

Jevnaker, T. (2015). Pushing administrative EU integration: The path towards European network codes for electricity. Journal of European Public Policy, 22(7), 927-947.

Kelemen, R. D., \& Tarrant, A. D. (2011). The political foundations of the Eurocracy. West European Politics, 34(5), 922-947.

Khuchua, N. (2009). Die Europäische Umweltagentur (EUA): Überblick und Bewertung der Effizienz. [The European Environment Agency (EEA): Efficiency overview and assessment]. Hanse Law Review, 5(1), 79-96. 
Kieser, A., \& Kubicek, H. (1992). Organisation. Berlin: Walter de Gruyter.

Klüver, H. (2012). Informational lobbying in the European Union: The effect of organisational characteristics. West European Politics, 35(3), 491-510.

Maggetti, M. (2009). The role of independent regulatory agencies in policy-making: A comparative analysis. Journal of European Public Policy, 16(3), 450-470.

Martens, M. (2010). Voice or loyalty? The evolution of the European Environmental Agency (EEA). Journal of Common Market Studies, 48(4), 881-901.

Riley, D. D., \& Brophy-Baermann, B. E. (2006). Bureaucracy and the policy process: Keeping the promises. Lanham, MD: Rowman \& Littlefield.

Rimkute, D. (2015). Explaining differences in scientific expertise use: The politics of pesticides. Politics and Governance, 3(1), 114-127.

Rimkute, D., \& Haverland, M. (2015). How does the European Commission use scientific expertise? Results from a survey of scientific members of the Commission's expert committees. Comparative European Politics, 13(4), 430-449.
Saerbeck, B. (2014). Unabhängige europäische Regulierungsagenturen. [Independent European regulatory agencies]. Wiesbaden: Springer VS.

Tarrant, A., \& Kelemen, R. D. (2017). Reconceptualizing European Union regulatory networks: A response to Blauberger and Rittberger. Regulation \& Governance, 11(2), 213-222.

Trondal, J., \& Peters, B. G. (2013). The rise of European administrative space: Lessons learned. Journal of European Public Policy, 20(2), 295-307.

Van Ooik, R. (2005). The growing importance of agencies in the EU: Shifting governance and the institutional balance. In D. M. Curtin \& R. A. Wessel (Eds.), Good governance and the European Union (pp. 125-152). Antwerp: Intersentia.

Wolff, S., \& Schout, A. (2013). Frontex as agency: More of the same? Perspectives on European Politics and Society, 14(3), 305-324.

Wonka, A., \& Rittberger, B. (2010). Credibility, complexity and uncertainty: Explaining the institutional independence of $29 \mathrm{EU}$ agencies. West European Politics, 33(4), 730-752.

\section{About the Authors}
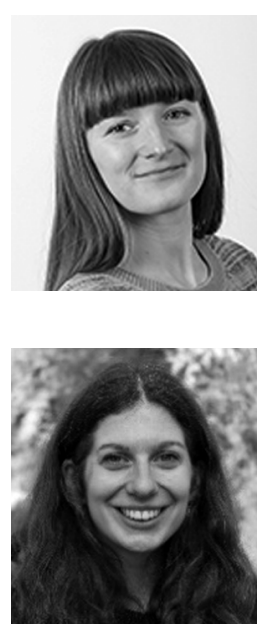

Torbjørg Jevnaker is a PhD Candidate at the Department of Political Science, University of Oslo, as well as a Research Fellow at the Fridtjof Nansen Institute, Norway. Her research focuses on the organization of public administration and regulatory policy. She is interested in EU agencies and EU energy and climate governance, including energy market regulation and emissions trading systems. Photo credit: Tron Trondal (2016).

Barbara Saerbeck is working as a Policy Officer at the Federation of German Consumer Organizations and is responsible for the energy sector. She is also associated with the Environmental Policy Research Centre at Freie Universität Berlin. Her research focuses on the role and influence of supra- and international public administrations (inter-)national energy, climate and biodiversity politics as well as on German and European environmental politics. 